\title{
Cryobiotechnology: A Double-Edged Sword for Obligate Plant Pathogens
}

\author{
Lei Zhao',2, Minrui Wang', Jingwei Li', Zhenhua Cui', \\ Gayle M. Volk', and Qiaochun Wang ${ }^{1,3, \dagger}$
}

\author{
'State Key Laboratory of Crop Stress Biology in Arid Region, College of Horticulture, \\ Northwest A\&F University, Yangling 712100, Shaanxi, P.R. China \\ ${ }^{2}$ College of Plant Protection, Northwest A\&F University, \\ Yangling 712100, Shaanxi, P.R. China \\ ${ }^{3}$ College of Horticulture, Qingdao Agricultural University, \\ Qingdao, Shandong, P.R. China \\ ${ }^{4}$ National Laboratory for Genetic Resources Preservation, \\ Fort Collins, CO 80521, U.S.A.
}

\begin{abstract}
Pathogen-free stock plants are required as propagation materials in nurseries and healthy materials are needed in germplasm exchange between countries or regions through quarantine programs. In addition, plant gene banks also prefer to maintain pathogen-free germplasm collections. Shoot tip cryotherapy is a novel biotechnology method whereby cryopreservation methods are used to eradicate obligate pathogens from vegetatively propagated plants. Long-term preservation of pathogens is necessary in all types of virus-related basic research and applications such as antigen preparation for virus detection by immunology-based methods, production of plant-based vaccines, genetic transformation to produce virus-derived resistant transgenic plants, and bionanotechnology to produce nano drugs. Obligate plant pathogens such as viruses and viroids are intracellular parasites that colonize only living cells of the hosts. Therefore, their long-term preservation is difficult. Cryotreatments cannot completely eradicate the obligate pathogens that do not infect meristematic cells and certain proportions of plants recovered from cryotreatments are still pathogen-infected. Furthermore, cryotreatments often fail to eradicate the obligate pathogens that infect meristematic cells. Cryopreservation can be used for the long-term cryopreservation of the obligate plant pathogens. Thus, cryobiotechnology functions as a double-edged sword for plant pathogen eradication and cryopreservation. This review provides updated a synthesis of advances in cryopreservation techniques for eradication and cryopreservation of obligate plant pathogens.
\end{abstract}

${ }^{\dagger}$ Corresponding author: Qiaochun Wang; qiaochunwang@ @wsuaf.edu.cn

Lei Zhao, Minrui Wang, and Jingwei Li contributed equally to this study.

Funding: This study was supported by National Natural Science Foundation of China (No. 31701761) and the Key Research and Development Program of Shaanxi Province (2018NY-101).

The author(s) declare no conflict of interest.

Accepted for publication 24 January 2019.

(C) 2019 The American Phytopathological Society

\section{Need for Both Plant Pathogen Eradication} and Preservation

Obligate plant pathogens such as viruses, viroids, and phytoplasmas have long threatened sustainable and profitable agricultural production. Although accurate data are lacking, these pathogens cause much greater economic losses than is generally recorded because the losses are frequently insidious and may be inconspicuous (Hadidi and Barba 2011; Hammond 2017).

Economically important plants such as horticultural, ornamental, and tuber crops are usually propagated vegetatively and are therefore particularly susceptible to infection by obligate pathogens, such as viruses, viroids, and phytoplasmas, that are transmitted to the planting materials from generation to generation through vegetative propagation (Hull 2002; Škorić 2017). Pathogen-free stock plants are required as propagation materials in nurseries (Barba et al. 2017; Laimer and Barba 2011) and clean materials are needed in germplasm exchange between countries or regions through quarantine programs (Reed and Foster 2011; Roy 2011). In addition, plant gene banks also prefer to maintain pathogen-free germplasm collections (Tavazza et al. 2013; Q. C. Wang and Valkonen 2009; Wang et al. 2009).

Pathogen management programs often require maintenance of pathogen-infected plants for use as positive controls (Hull 2002). Viruses are also needed as sources for antigen preparation for use in immunological assays, the most widely used method in virus detection (Cambra et al. 2011), to develop virus-resistant plants through genetic transformation (Kumar et al. 2017), and to produce plant-based vaccines (Salazar-González et al. 2015) and nanodrugs (Lomonossoff and Evans 2011). All these programs make it necessary to maintain key collections of the pathogens. This review addresses the use of cryobiotechnology to eradicate pathogens from infected plants and to cryopreserve pathogens in their host plants.

\section{Pathogen Eradication by Shoot Tip Cryotherapy}

Cryopreservation refers to the storage of biological samples in liquid nitrogen $\left(\mathrm{LN},-196^{\circ} \mathrm{C}\right)$ or liquid nitrogen vapor (LNV, approx. -165 to $-190^{\circ} \mathrm{C}$ ) and is currently considered an ideal means for 
the long-term preservation of vegetatively propagated plant germplasm (B. Wang et al. 2014; M. R. Wang et al. 2018a). Once frozen in LN, physiological metabolism and cell divisions of the cryo-stored samples are essentially halted and, theoretically, plant materials can be stored without any change in viability for extended lengths of time (B. Wang et al. 2014; M. R. Wang et al. 2018a).

Shoot tip cryotherapy is a novel biotechnology for plant pathogen eradication, which was developed based on cryopreservation techniques (B. Wang et al. 2014; M. R. Wang et al. 2018a; Q. C. Wang and Valkonen 2009; Q. C. Wang et al. 2009). Viruses are distributed unevenly within plants (White 1934), with low levels or even a virusfree area at upper parts of the apical dome (AD), particularly for phloem-limited viruses. When shoot tips are cryopreserved in LN, only the cells that are less differentiated, have a high nucleo-cytoplasmic ratio, and contain low levels of free water are able to survive (Bi et al. 2018a; Brison et al. 1997; Helliod et al. 2002; Li et al. 2016; Q. C. Wang and Valkonen 2008a, 2008b; Q. C. Wang et al. 2008). In most plant systems, the uppermost layers of the AD and the youngest leaf primordia (LP) survive and cells in the lower parts of the $\mathrm{AD}$ and older LP are killed after cryo-treatment (Bi et al. 2018a; Helliod et al. 2002; Li et al. 2016; Q. C. Wang and Valkonen 2008a, 2008b; Q. C. Wang et al. 2008). As a result, exposure to LN may kill the differentiated pathogen-infected cells and allow the healthy (pathogen-free) cells to survive and regenerate into pathogen-free plants (Bi et al. 2018a; Brison et al. 1997; Helliod et al. 2002; Li et al. 2016; Q. C. Wang and Valkonen 2008a, 2008b; Q. C. Wang et al. 2008). The working model of shoot tip cryotherapy for pathogen eradication can be found in a review paper published by Q. C. Wang and Valkonen (2009).

In 1997, Brison et al. (1997) published the first successful elimination of plum pox virus from a Prunus root stock using a vitrification cryopreservation technique. Since then, several studies have shown that cryopreservation can efficiently eradicate obligate pathogens including viruses, phytoplasmas, and bacteria (B. Wang et al. 2014; M. R. Wang et al. 2018a; Q. C. Wang and Valkonen 2009; Q. C. Wang et al. 2009). Shoot tip cryotherapy often failed to eradicate pathogens that infect the meristematic cells of the AD (Jeon et al. 2016; Kushnarenko et al. 2017; Vieira et al. 2015; Q. C. Wang et al. 2008; Zhao et al. 2018); however, a combination of thermotherapy, cold therapy, or chemotherapy with cryotherapy can eliminate these specific pathogens (Jeon et al. 2016; Kushnarenko et al. 2017; Vieira et al. 2015; Q. C. Wang et al. 2008; Zhao et al. 2018). At this time, thermotherapy followed by cryotherapy is considered the most efficient method for the eradication of plant viruses (Q. C. Wang et al. 2008; Zhao et al. 2018). To date, shoot tip cryotherapy has been applied to 21 plant species for successfully eradication of 28 viruses belonging to 18 genera of eight families and one unassigned family (Table 1), three viroids belonging to two genera of two families (Table 2), and two phytoplasmas belonging to one genus, and one bacterium (Table 3 ). These pathogens include a wide diversity of obligate plant pathogens and these plant species represent the world's most economically important vegetatively propagated crops.

Shoot tip culture (also called meristem culture) has traditionally been one of the most successful methods employed to produce pathogen-free plants (Barba et al. 2017; Laimer and Barba 2011; Panattoni et al. 2013). Plant shoot tips contain undifferentiated cells, which are capable of continuous cellular division and eventually give rise to a shoot (Q. C. Wang et al. 2009). Shoot tip culture is the growth of shoot tips on artificial medium under aseptic conditions (Q. C. Wang et al. 2009). Cryotherapy for pathogen eradication has at least two prominent advantages over shoot tip culture: 1) cryotherapy consistently produces higher pathogen eradication frequencies than shoot tip culture, with the pathogen eradication frequencies averaging $55 \%$ for 27 viruses from 21 plant species, compared with $24 \%$ for shoot tips from the same pathogens and plants (Table 1). The higher eradication efficiency obtained in cryotherapy allows a smaller number of regenerated shoots to be pathogen-indexed to identify those free of the pathogen, thus reducing the cost and labor required in shoot tip culture for pathogen detection; 2) shoot tips (1.0 to $1.5 \mathrm{~mm}$ in size) containing 3 to $4 \mathrm{LP}$ are frequently used in cryotherapy for pathogen eradication (B. Wang et al. 2014; M. R. Wang et al. 2018a; Q. C. Wang and Valkonen 2009; Q. C. Wang et al. 2009), which are larger than the 0.2 to $0.5 \mathrm{~mm}$ shoot tips containing 1 to $2 \mathrm{LP}$ required for shoot tip culture (Barba et al. 2017; Laimer and Barba 2011; Panattoni et al. 2013). Thus, cryotherapy eliminates the highly skilled, labor-intensive technique of excision of small shoot tips, which is critical for pathogen eradication in shoot tip culture. Although the number of plants regenerated after shoot tip cryotherapy may be lower than those obtained after shoot tip culture (Q. C. Wang and Valkonen 2009; B. Wang et al. 2014; M. R. Wang et al. 2018a; Q. C. Wang et al. 2009), a few pathogen-free shoots can be micropropagated to produce the necessary number of plants in a short time. Genotype-specific responses are common in both cryotherapy and shoot tip culture (Barba et al. 2017; Laimer and Barba 2011; B. Wang et al. 2014; M. R. Wang et al. 2018a; Q. C. Wang and Valkonen 2009; Q. C. Wang et al. 2009).

Successful shoot tip cryopreservation is dependent upon several critical steps including in vitro culture, shoot tip preculture, cryoprotection, and dehydration, as well as $\mathrm{LN}$ exposure and postculture for plant recovery (Benson 2008; Harding 2004; B. Wang et al. 2014). This combination of steps, particularly the use of in vitro culture for the propagation and maintenance of stock cultures before cryotreatment and for shoot recovery after cryo-treatments, may alter the genetic composition of the regenerated plants (Benson 2008; Harding 2004; B. Wang et al. 2014, 2018a). Thus, it is necessary to assess genetic stability and evaluate field performance in pathogen-free plants produced by cryotechniques. There have been a number of studies on assessments of genetic stability and observations of field performance of the plants recovered after cryo-treatments and the results are quite promising (Benson 2008; Harding 2004; B. Wang et al. 2014; M. R. Wang et al. 2018a), but such studies in pathogen-free plants recovered from cryotherapy have been quite limited. The ploidy levels remained stable in artichoke latent virus (ArLV)-free plants (Tavazza et al. 2013) and jujube witches' broom phytoplasma-free plants (R. R. Wang et al. 2015) recovered after cryotherapy. Using in vitro culture to compare vegetative growth, microtuber production and salt tolerance in virus-free potato plants derived from cryotherapy and virus-infected plants, Li et al. (2018a) found vegetative growth and root growth were significantly greater in the virus-free plants than in those that were virusinfected. Total microtuber number and percentage of microtubers that were $\geq 5 \mathrm{~mm}$ in diameter (commercial microtubers) were significantly higher in the virus-free plants than in virus-infected ones. Furthermore, virus-free plants were also much tolerant to salt stress than the virus-infected ones ( $\mathrm{Li}$ et al. 2018a).

Cryopreservation procedures are currently available for many major economically important, vegetatively propagated crops like potato (B. Wang et al. 2008); sweetpotato (Feng et al. 2011), cassava (Dumet et al. 2011), garlic (Ellis et al. 2006), grapevine (Bi et al. 2017, 2018b), apple (M. R. Wang et al. 2018a), and citrus (Volk et al. 2012), thus facilitating the wider application of cryotherapy for pathogen eradication. Comprehensive information on the development in and advances of cryotherapy for pathogen eradication can be found in several excellent reviews (B. Wang et al. 2014; M. R. Wang et al. 2018a; Q. C. Wang and Valkonen 2009; Q. C. Wang et al. 2009).

\section{Pathogen Cryopreservation}

Obligate plant pathogens including viruses, viroids, and phytoplasmas replicate inside the living cells of the host and therefore colonize only living host cells (Flores et al. 2017; Hull 2002). As a result, preservation of obligate plant pathogens is difficult. Over the past several decades, various methods have been developed to preserve plant viruses, including freezing (Fukumoto 2008; Fukumoto and Tochinara 1998), freeze-drying (Fukumoto 2008; Fukumoto and Tochinara 1998; Hollings and Stone 1970; Purcifull 1975; Yordanova et al. 2000), dehydration by physical (Grivell et al. 1971) and chemical drying (McKinney et al. 1965), and in 
Table 1. Virus eradication in plants recovered from cryopreserved shoot tips (Cryo) and shoot tip culture (STC)

\begin{tabular}{|c|c|c|c|c|}
\hline \multirow[b]{2}{*}{ Pathogen } & \multirow[b]{2}{*}{ Plant species } & \multicolumn{2}{|l|}{ Pathogen-free $(\%)$} & \multirow[b]{2}{*}{ Ref. } \\
\hline & & Cryo & STC & \\
\hline \multicolumn{5}{|l|}{ Betaflexiviridae, Capillovirus } \\
\hline \multirow[t]{5}{*}{ Apple stem grooving virus (ASGV) } & Malus $\times$ domestica & 0 & 0 & Li et al. 2016 \\
\hline & & 50 & $\mathrm{NT}^{\mathrm{a}}$ & Romadanova et al. 2016 \\
\hline & & 0 & 0 & Zhao et al. 2018 \\
\hline & & 30-100 (Thermo+cryo) ${ }^{\mathrm{b}}$ & 22 & Zhao et al. 2018 \\
\hline & & 90 & 0 & Bettoni et al. 2018 \\
\hline \multicolumn{5}{|l|}{ Betaflexiviridae, Carlavirus } \\
\hline \multirow{2}{*}{ Garlic common latent virus (GCLV) } & Allium sativum & 63 & 13 & Vieira et al. 2015 \\
\hline & & 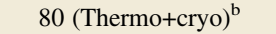 & 13 & Vieira et al. 2015 \\
\hline \multirow[t]{2}{*}{ Potato virus M (PVM) } & Solanum tuberosum & 50 & NT & Kushnarenko et al. 2017 \\
\hline & & 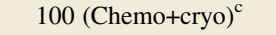 & NT & Kushnarenko et al. 2017 \\
\hline \multirow{2}{*}{ Potato virus S (PVS) } & & 0 & NT & Kushnarenko et al. 2017 \\
\hline & & $100(\text { Chemo+cryo })^{\mathrm{c}}$ & NT & Kushnarenko et al. 2017 \\
\hline \multicolumn{5}{|l|}{ Betaflexiviridae, Foveavirus } \\
\hline \multirow[t]{3}{*}{ Apple stem pitting virus (ASPV) } & M. $\times$ domestica & 83 & 0 & Li et al. 2016 \\
\hline & & 40 & NT & Romadanova et al. 2016 \\
\hline & & 100 & 0 & Bettoni et al. 2018 \\
\hline Betaflexiviridae, Nepovirus & & & & \\
\hline Grapevine fanleaf virus (GFLV) & Vitis vinifera & 78 & 82 & Marković et al. 2015 \\
\hline Betaflexiviridae, Potexvirus & & & & \\
\hline Potato virus X (PVX) & S. tuberosum & 59 & 36 & Bai et al. 2012 \\
\hline Betaflexiviridae, Trichovirus & & & & \\
\hline Apple chlorotic leaf spot virus (ACLSV) & Malus & 52 & NT & Romadanova et al. 2016 \\
\hline Bromoviridae, Cucumovirus & M. $\times$ domestica & 100 & 0 & Bettoni et al. 2018 \\
\hline Cucumber mosaic virus (CMV) & Musa & 34 & 4 & Brison et al. 1997 \\
\hline Bromoviridae, Ilarvirus & Malus & 89 & NT & Romadanova et al. 2016 \\
\hline Apple mosaic virus (ApMV) & Humulus lupulus & 0 & 7 & Nukaria et al. 2014 \\
\hline Caulimoviridae, Badnavirus & & & & \\
\hline Banana streak virus (BSV) & Musa & 90 & 76 & Brison et al. 1997 \\
\hline Closteroviridae, Ampelovirus & & & & \\
\hline Grapevine leafroll-associated virus $2(\mathrm{GLRaV}-2)$ & $V$. vinifera & 100 & NT & Pathirana et al. 2013 \\
\hline Closteroviridae, Closterovirus & & & & \\
\hline Grapevine leafroll-associated virus 1 (GLRaV-1) & $V$. vinifera & 100 & NT & Pathirana et al. 2013 \\
\hline Grapevine leafroll-associated virus 3 (GLRaV-3) & $V$. vinifera & 100 & NT & Pathirana et al. 2013 \\
\hline & $V$. vinifera & 100 & 100 & Marković et al. 2015 \\
\hline Closteroviridae, Crinivirus & & & & \\
\hline Sweet potato chlorotic stunt virus (SPCSV) & Ipomoea batatas & 100 & 100 & Q. C. Wang and Valkonen 2008b \\
\hline Luteoviridae, Polerovirus & & & & \\
\hline Potato leafroll virus (PLRV) & S. tuberosum & 86 & 50 & Q. C. Wang et al. 2006 \\
\hline & & 37 & 14 & Dhital et al. 2009 \\
\hline & & 98 & 48 & Yi et al. 2014 \\
\hline Potyviridae, Macluravirus & & & & \\
\hline Artichoke latent virus (ArLV) & Cynara cardunculus L. var. scolymus & 100 & 0 & Tavazza et al. 2013 \\
\hline & C. scolymus & 100 & NT & Taglienti et al. 2013 \\
\hline Potyviridae, Potyvirus & & & & \\
\hline Leek yellow stripe virus (LYSV) & A. sativum & 94 & 35 & Vieira et al. 2015 \\
\hline & & $100(\text { Thermo+cryo })^{\mathrm{b}}$ & 35 & Vieira et al. 2015 \\
\hline Onion yellow dwarf virus (OYDV) & & 88 & 26 & Vieira et al. 2015 \\
\hline & & 90 (Thermo+cryo) $^{\mathrm{b}}$ & 26 & Vieira et al. 2015 \\
\hline Plum pox virus (PPV) & Prunus & 50 & 20 & Brison et al. 1997 \\
\hline & P. armeniaca & 100 & NT & Şeker et al. 2015 \\
\hline Potato virus Y (PVY) & S. tuberosum & 95 & 62 & Q. C. Wang et al. 2006 \\
\hline & & 42 & 11 & Dhital et al. 2009 \\
\hline & & 94 & 42 & Yi et al. 2014 \\
\hline Sweet potato feathery mottle virus (SPFMV) & I. batatas & 100 & 10 & Q. C. Wang and Valkonen 2008b \\
\hline Yam mosaic virus (YMV) & Dioscorea opposita & 90 & 40 & Jong et al. 2013 \\
\hline Tombusviridae, Alphacarmovirus & & & & \\
\hline Pelargonium flower break virus (PFBV) & Pelargonium $\times$ hortorum & 0 & 0 & Gallard et al. 2011 \\
\hline Tombusviridae, Pelarspovirus & & & & \\
\hline Pelargonium line pattern virus (PLPV) & P. $\times$ hortorum & 0 & 0 & Gallard et al. 2011 \\
\hline & P. $\times$ peltatum & 0 & 0 & Gallard et al. 2011 \\
\hline Tymovirales, Vitivirus & & & & \\
\hline Grapevine virus A (GVA) & $V$. vinifera & 97 & 12 & Q. C. Wang et al. 2003 \\
\hline & & 42 & 0 & Bayati et al. 2011 \\
\hline family unassigned, Idaeovirus & & & & \\
\hline Raspberry bushy dwarf virus (RBDV) & Rubus idaeus & 0 & 0 & Q. C. Wang et al. 2008 \\
\hline & & $33(\text { Thermo+cryo) })^{b}$ & 0 & Q. C. Wang et al. 2008 \\
\hline Average & & 55 & 24 & \\
\hline
\end{tabular}

\footnotetext{
${ }^{\mathrm{a}} \mathrm{NT}=$ not tested.

${ }^{\mathrm{b}}$ Thermo+cryo $=\mathrm{a}$ combination of thermotherapy and cryotherapy.

${ }^{\mathrm{c}}$ Chemo+cryo $=\mathrm{a}$ combination of chemotherapy and cryotherapy.
} 
vitro culture (Chen et al. 2003; Infante et al. 2008). A few major drawbacks limit the wider application of the available techniques to virus storage. Some viruses were not stable after storage in the freezedried state (Fukumoto and Tochinara 1998; Hollings and Stone 1970; Purcifull 1975; Yordanova et al. 2000). The infectivity of the stored virus decreases as the storage durations increase (Yordanova et al. 2000). The viruses that have been stored freezing, freezedrying, and dehydration can be transmitted to the target plants only by mechanical inoculation (Fukumoto and Tochinara 1998; Grivell et al. 1971; Hollings and Stone 1970; McKinney et al. 1965; Purcifull 1975; Yordanova et al. 2000). Unfortunately, some plant viruses and viroids cannot be transmitted by mechanical inoculation (Hull 2002; Škorić 2017). In addition, in vitro culture for virus storage requires a lot of labor and has risks of contamination, thus resulting in total loss of the stored pathogens ( $\mathrm{Li}$ et al. 2018b; M. R. Wang et al. 2018c).

Although cryotreatment can efficiently eradicate pathogens, a certain proportion of plants recovered following cryotreatment are still pathogen-infected, depending on the pathogen-host combinations (Tables 1, 2 and 3, Fig. 1). This is particularly true for the viruses that infect the meristematic cells of the shoot tip and viroids (Bai et al. 2012; Gallard et al. 2011; Jeon et al. 2016; Li et al. 2016; Li et al. 2018b; Q. C. Wang et al. 2008; Zhang et al. 2014; Zhao et al. 2018; Fig. 1). These data indicate that cryopreservation techniques developed for plants have potential application to pathogen cryopreservation.

M. R. Wang et al. (2018c) reported successful cryopreservation of apple stem grooving virus (ASGV), a virus that infects the meristematic cells of the AD. In this study, apple 'Gala' shoot tips $(1.5 \mathrm{~mm}$, with 5 to 6 LP) were excised from the 4-week-old ASGV-infected in vitro stock shoots and subjected to encapsulation-vitrification and droplet-vitrification cryogenic procedures. Following cryopreservation, 62 to $67 \%$ shoot regrowth levels were observed after cryoexposure, and ASGV was cryopreserved in $100 \%$ recovered plants. Li et al. (2018b) applied droplet-vitrification cryopreservation to preserve potato leafroll virus (PLRV), potato virus S (PVS), and potato spindle tuber viroid (PSTVd) in potato 'Zihuabai' shoot tips $(1.5 \mathrm{~mm}$, with 5 to $6 \mathrm{LP}$ ) excised from diseased in vitro shoots following cryopreservation. About $60 \%, 58 \%$, and $52 \%$ shoot regrowth was obtained in cryopreserved shoot tips infected with PLRV, PVS, and PSTVd, respectively; $35 \%$ of the recovered plants were infected with PLRV and $100 \%$ of the recovered plants were infected with PVS or PSTVd (Li et al. 2018b). Li et al. (2019) reported chrysanthemum stunt viroid (CSVd) and chrysanthemum chlorotic mottle viroid $(\mathrm{CChMVd})$ were cryopreserved in $100 \%$ shoots recovered from shoot tips following encapsulation-vitrification cryopreservation. In this study, they further found size of shoot tips, viroid infection levels (high and low infection), and viroid infection status (single and coinfection) did not affect viroid cryopreservation levels.

Three gene fragments $(3,813$ nucleotides in total) containing the coat protein and movement protein of ASGV were sequenced in cryopreserved and non-cryopreserved infected plant materials (M. R. Wang et al. 2018c). Only five nucleotide differences were detected between the cryopreserved ASGV and the non-cryopreserved virus, which resulted in a $99.87 \%$ nucleotide identity level between the treatments (M. R. Wang et al. 2018c). Although in vitro shoot multiplication rates were slower in ASGV-cryopreserved shoots after the first 8 weeks of subculture following cryopreservation, compared with multiplication rates of non-cryopreserved infected shoots, multiplication levels were similar after 16 weeks of subculture (M. R. Wang et al. 2018c). Likewise, in vitro shoot multiplication rates were

Table 2. Viroid eradication in plants recovered from cryopreserved shoot tips (Cryo) and shoot tip culture (STC)

\begin{tabular}{|c|c|c|c|c|}
\hline \multirow[b]{2}{*}{ Pathogen } & \multirow[b]{2}{*}{ Plant species } & \multicolumn{2}{|c|}{ Pathogen-free $(\%)$} & \multirow[b]{2}{*}{ Ref. } \\
\hline & & Cryo & STC & \\
\hline \multirow{3}{*}{$\begin{array}{l}\text { Avsunviroidae, Pelamoviroid } \\
\text { Chrysanthemum chlorotic mottle viroid } \\
\text { (CCMVd) }\end{array}$} & & & & \\
\hline & Chrysanthemum morifolium & 4 & $\mathrm{NT}^{\mathrm{a}}$ & Jeon et al. 2016 \\
\hline & & 0 & NT & Li et al. $2018 \mathrm{a}$ \\
\hline \multicolumn{5}{|l|}{ Pospiviroidae, Pospiviroid } \\
\hline \multirow[t]{4}{*}{ Chrysanthemum stunt viroid (CSVd) } & C. morifolium & 0 & 0 & Li et al. 2018a \\
\hline & & 13 & 0 & Jeon et al. 2016 \\
\hline & & $20(\text { Cold }+ \text { cryo })^{b}$ & 0 & Jeon et al. 2016 \\
\hline & Argyranthemum maderense & 0 & 0 & Zhang et al. 2014 \\
\hline Potato spindle tuber viroid (PSTVd) & Solanum tuberosum & 0 & 0 & Bai et al. 2012; Li et al. 2018b \\
\hline
\end{tabular}

Table 3. Eradication of phytoplasma and bacterium in plants recovered from cryopreserved shoot tips (Cryo) and shoot tip culture (STC)

\begin{tabular}{|c|c|c|c|c|}
\hline \multirow[b]{2}{*}{ Pathogen } & \multirow[b]{2}{*}{ Plant species } & \multicolumn{2}{|c|}{ Pathogen-free (\%) } & \multirow[b]{2}{*}{ Ref. } \\
\hline & & Cryo & STC & \\
\hline \multicolumn{5}{|l|}{$\begin{array}{l}\text { Phytoplasma } \\
\text { Firmicutes, Acholeplasmataceae }\end{array}$} \\
\hline Candidatus phytoplasma ziziphi & Ziziphus jujuba & 100 & 0 & R. R. Wang et al. 2015 \\
\hline $\begin{array}{l}\text { Sweet potato little leaf phytoplasma } \\
\text { Bacterium }\end{array}$ & Ipomoea batatas & 100 & 10 & Q. C. Wang and Valkonen $2008 \mathrm{~b}$ \\
\hline Proteobacteria, Liberobacter & & & & \\
\hline Citrus Huanglongbing & $\begin{array}{l}\text { Citrus limon } \\
\text { C. maxima } \\
\text { C. reticulata } \\
\text { C. sinensis }\end{array}$ & $\begin{array}{l}91 \\
94 \\
93 \\
92\end{array}$ & $\begin{array}{l}23 \\
23 \\
23 \\
23\end{array}$ & Ding et al. 2008 \\
\hline
\end{tabular}


slower for PLRV-, PVS-, and PSTVd-cryopreserved shoots after the first the 12 weeks of subculture and were similar to the noncryopreserved controls after 18 weeks of subculture (Li et al. 2018b). These data suggest that once a single virus-infected shoot is obtained, it can be easily micropropagated to produce additional plants. Analysis by qRT-PCR showed pathogen titers were lower in the viruscryopreserved shoots than in non-cryopreserved shoots in the first 4 weeks of subculture and that they gradually increased as subculture

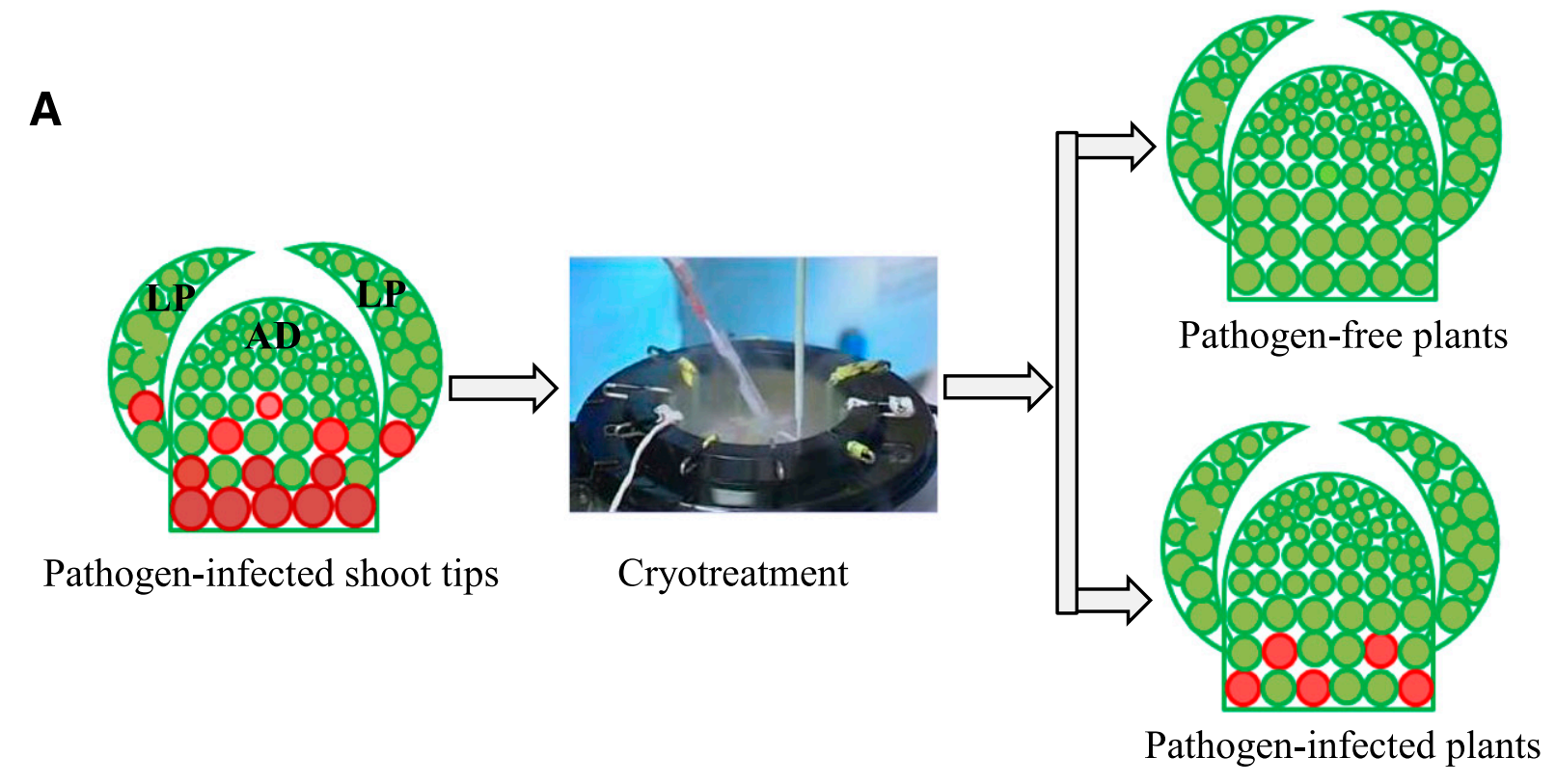

B

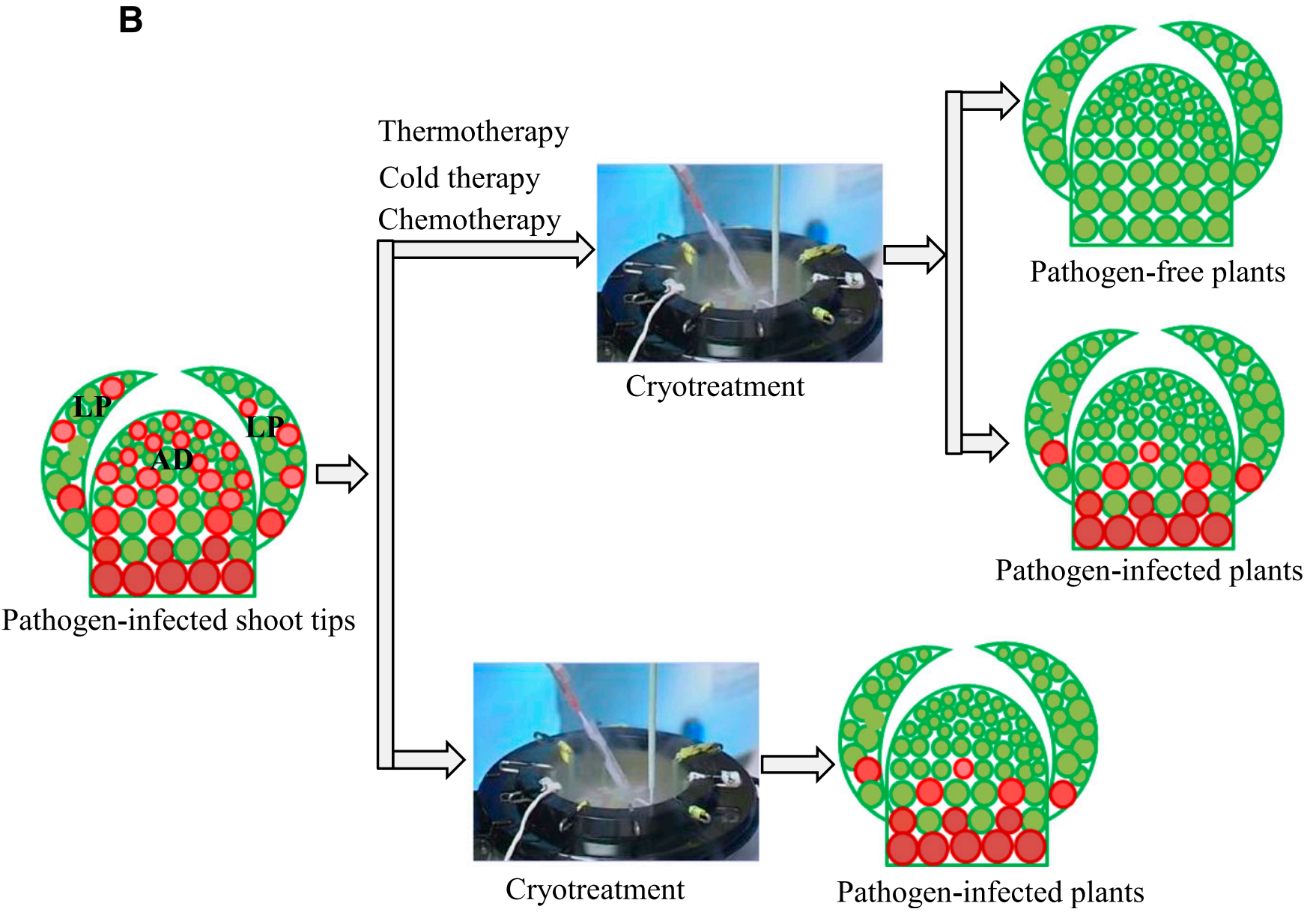

Fig. 1. Schematic diagrams of shoot tip cryotherapy for obligate plant pathogen eradication and preservation in in vitro shoots infected with pathogens that do not infect (A) and infect (B) meristematic cells of shoot tips. Shoot tip cryotreatment can efficiently eradicate pathogens that do not infect meristematic cells of shoot tips (A). A certain proportion of plants recovered following cryotreatment are still pathogen-infected, depending on the host-pathogen combinations (A). Adjustments of cryoprocedures can increase or decrease pathogen eradication, while decreasing or increasing pathogen preservation (A). Combining thermotherapy or cold therapy or chemotherapy with cryotreatment can efficiently eradicate pathogens that infect meristematic cells of shoot tips, while decreasing pathogen preservation (B). Cryotreatment alone often fails to eradicate pathogens that infect meristematic cells of shoot tips, thus increasing pathogen preservation (B). Cells in green are healthy cells and in red are pathogen-infected cells. $A D=$ apical dome; $L P=$ leaf primordium. 
durations increased and reached similar levels to those that were not cryopreserved after 16 weeks for ASGV (M. R. Wang et al. 2018c) and 21 weeks for PLRV, PVS, and PSTVd (Li et al. 2018b) of subculture following cryopreservation. Cryopreserved pathogens can be efficiently transmitted between apple plants by in vitro micrografting (M. R. Wang et al. 2018c) or between potato plants by in vivo grafting (Li et al. 2018b), and from apple or potato to Nicotiana benthamiana by mechanical inoculation (Li et al. 2018b; M. R. Wang et al. 2018c). Cryopreserved-ASGV, PLRV, PVS, PSTVd, CSVd, and CChMVd represent a diverse range of viruses and viroids with respect to their infectious ability and taxonomy.

All the above data demonstrate that: 1) cryopreservation can maintain pathogens within living shoot tips; 2) cryopreserved pathogens are likely to be genetically stable; 3 ) cryopreserved shoots harboring pathogens can be efficiently micropropagated; and 4) cryopreserved pathogens can be transmitted by vegetative propagation and mechanical inoculation. These are the major concerns with respect to the long-term preservation of obligate plant pathogens.

Interestingly, when applying cryotherapy for virus eradication from in vitro shoots of apple rootstocks 'M9' and 'M26' that were coinfected with apple stem pitting virus (ASPV) and ASGV, Li et al. (2016) found that 80 to $85 \%$ of the plants recovered following cryotherapy were free of ASPV, while none of them were free of ASGV. ASPV cannot, while ASGV can, infect meristematic cells of the shoot tips, and the former and latter represent easy-to-eradicate and difficult-to-eradicate pathogens, respectively. Thus, cryotreatments can separate easy-to-eradicate pathogens from difficultto-eradicate ones and cryopreserve the latter ( $\mathrm{Li}$ et al. 2016; M. R. Wang et al. 2018c). Preservation of single-infected materials is of importance in the basic and applied pathogen research. An understanding of the pathogen-host response to cryo-exposure may reveal new information about where the pathogen is harbored within plants.

\section{Effects of Combined Therapies}

Thermotherapy, cold therapy, and chemotherapy have traditionally been used to eradicate pathogens from plants (Barba et al. 2017; Laimer and Barba 2011; Liu et al. 2016; Panattoni et al. 2013). Each of these methods has been coupled with cryotherapy to improve pathogen eradication (Jeon et al. 2016; Kushnarenko et al. 2017; Vieira et al. 2015; Q. C. Wang et al. 2008; Zhao et al. 2018), while decreasing pathogen preservation (Fig. 1).

Thermotherapy reduces virus titer, inhibits virus movement into the $\mathrm{AD}$, and enhances virus-induced gene silencing (Liu et al. 2016; L. P. Wang et al. 2010; M. R. Wang et al. 2018c; Q. C. Wang et al. 2008; Zhao et al. 2018). Thermotherapy also reduces the ability of cells to survive after LN exposure (Q. C. Wang et al. 2008; Zhao et al. 2018). When thermotherapy is combined with cryotherapy, the pathogen-free areas are larger and fewer cells of the shoot tips survive the cryo-treatment (Q. C. Wang et al. 2008; Zhao et al. 2018). This increases the effectiveness of pathogen eradication. Shoot tip cryotherapy alone completely failed to eradicate raspberry bushy dwarf virus (RBDV) from in vitro diseased shoots of raspberry (Rubus idaeus) because it infected the $\mathrm{AD}$ of the shoot tips (Q. C. Wang et al. 2008). In vitro infected shoots were thermo-treated for 28 to 35 days at an alternating temperature of $38 / 26^{\circ} \mathrm{C}(16 \mathrm{~h}$ day $/ 8 \mathrm{~h}$ night $)$. Shoot tips $(1.0 \mathrm{~mm}$ in size $)$ were then excised from the treated shoots and cryopreserved using an encapsulation-vitrification procedure. This combination of thermotherapy and cryotherapy resulted in 33 to $35 \%$ of the recovered plants being free of RBDV (Q. C. Wang et al. 2008). Similarly, shoot tip cryotherapy alone did not eradicate ASGV from in vitro apple plants (Li et al. 2016); however, a combination of thermotherapy and cryotherapy resulted in 30 to $100 \%$ ASGV-free plants for four apple cultivars and one rootstock (Zhao et al. 2018).

Cold therapy inhibits viroid replication, reduces viroid titer, and prevents viroid movement in the hosts (Barba et al. 2017; Jeon et al. 2016; Zhang et al. 2016). Cold therapy of in vitro shoots before cryotherapy was found to improve eradication of chrysanthemum stunt viroid (CSVd) (Jeon et al. 2016). In this work, viroid-infected in vitro stock plants of chrysanthemum 'Borami' were incubated at $4^{\circ} \mathrm{C}$ for 4 weeks and shoot tips containing 1 to $2 \mathrm{LP}$ were excised and cryopreserved. This combination of cold therapy and cryotherapy achieved $20 \%$ CSVd-free plants, compared with $13 \%$ produced by cryotherapy alone.

Chemotherapy inhibits synthesis of viroid RNA, decreases viroid titer, and enlarges viroid-free areas in the shoot tips (Barba et al. 2017; Crotty et al. 2000; Dawson and Lozoya 1984). Kushnarenko et al. (2017) reported that a combination of chemotherapy and cryotherapy improved the eradication of potato virus $\mathrm{M}$ (PVM) and PVS They found that shoot tip cryotherapy produced $20 \%$ and $57 \%$ PVMfree plants in potato 'Astana' and 'Nikitka,' respectively, but failed to eradicate PVS in the same two cultivars. When in vitro shoots were cultured on MS medium with $100 \mathrm{mg} \mathrm{liter}^{-1}$ ribavirin for 135 days with 45 day subcultures prior to shoot tip cryopreservation, $100 \%$ of the regenerated plants were both PVM- and PVS-free for four potato cultivars.

Data addressed above suggest that thermotherapy, cold therapy, or chemotherapy applied before cryotherapy can work as triggers, which may regulate eradication and cryopreservation of pathogens that infect meristematic cells of the AD: pressing the trigger can efficiently eradicate them, while closing the trigger can efficiently cryopreserve them (Fig. 1).

\section{Cryoprocedural Changes that Affect Cryotherapy}

For cryotherapy to be successful, the plant cells that survive after LN exposure must usually be limited to the $\mathrm{AD}$ and youngest LP. Most of the existing studies of shoot tip cryotherapy claimed pathogen eradication despite the size of the shoot tips (Bi et al. 2018a; Brison et al. 1997; Ding et al. 2008; Helliod et al. 2002; Li et al. 2016; B. Wang et al. 2014; M. R. Wang et al. 2018a; Q. C. Wang and Valkonen 2008a, 2008b, 2009; Q. C. Wang et al. 2003, 2009). Recently, Jeon et al. (2016) found that the CSVd-free frequency of cryotreated shoot tips of chrysanthemum was higher (13\%) in shoot tips with 1 to 2 LPs than the $7 \%$ in those with 3 to 4 LPs. In potato, PLRV was completely eradicated by cryotherapy in $0.5 \mathrm{~mm}$-shoot tips

\section{Glossary of terminology}

Chemotherapy: Exogenous application of chemicals to the infected cultures grown in vitro culture medium to produce pathogen-free plants.

Cold therapy: application of low temperatures to treat the infected cultures for production of pathogen-free plants.

Cryopreservation: the storage of biological samples in liquid nitrogen $\left(\mathrm{LN},-196^{\circ} \mathrm{C}\right)$ or liquid nitrogen vapor (LNV, approx. -165 to $\left.-190^{\circ} \mathrm{C}\right)$.

Obligate plant pathogen: a pathogen that replicates inside the living cells of the host and colonizes only living host cells, such as virus, viroid, and phytoplasma.

Pathogen: a microbe that causes disease.

Pathogen eradication: removal of pathogens from living plants.

Phytoplasma: an intracellular, cell wall-less bacterium that lives as obligate pathogens in sieve elements of plants.

Shoot tip (or meristem): terminal tissue of a shoot consisting of apical dome and a few leaf primordia that are composed of undifferentiated cells capable of continuous cellular division giving rise to a shoot.

Shoot tip cryotherapy: treatment of the infected shoot tips in liquid nitrogen to eradicate plant pathogens from the infected shoot tips. Shoot tip culture (or meristem culture): culture of shoot tips (or meristems) on an artificial medium under aseptic conditions.

Thermotherapy: application of high temperatures to treat the infected cultures grown in vitro or in vivo for production of pathogen-free plants.

Viroid: the smallest infectious pathogens composed solely of a short strand of circular, single-stranded RNA without coat protein.

Virus: a small infectious pathogen that replicates only inside the living cells of other organisms and causes disease. Viral particles (also known as virions) consist of the genetic material made from either DNA or RNA, which are protected by a coat protein or a lipoprotein. 
containing 2 to $3 \mathrm{LP}$, while $63 \%$ of plants were virus-free in $1.5 \mathrm{~mm}$ shoot tips containing 5 to $6 \mathrm{LP}$ (Li et al. 2018b); however, the size of the shoot tips did not affect the virus eradication frequencies of PVS and PSTVd. These data indicate that in some pathogen-host combinations, the size of shoot tips size used for cryotherapy may be significant for pathogen eradication.

Vitrification-based cryopreservation procedures are dependent upon the use of plant vitrification solutions (PVSs). PVS2 (Sakai et al. 1990) and PVS3 (Nishizawa et al. 1993) were the most frequently used in vitrification-based cryogenic procedures. PVS2 contains $30 \%(\mathrm{w} / \mathrm{v})$ glycerol, $15 \%(\mathrm{w} / \mathrm{v})$ ethylene glycol, $15 \%(\mathrm{w} / \mathrm{v})$ dimethyl sulfoxide (DMSO), and $0.4 \mathrm{M}$ sucrose in Murashige and Skoog (Murashige and Skoog 1962) medium (MS). PVS3 contains $50 \%$ (w/v) glycerol and 0.4 M sucrose in MS (M. R. Wang et al. 2018c). The type of plant vitrification solution utilized may affect the efficiency of pathogen eradication. About 13\% of CSVd-free chrysanthemum plants were obtained in cryo-treated shoot tips when PVS2 was used and no viroid-free plants regenerated when PVS3 was used (Jeon et al. 2016). Following cryo-treatments, only cells in the AD survived in PVS2-treated shoots; in comparison, more cells survived in the PVS3-treated shoot tips, thus resulting in higher levels of eradication efficiency with PVS2 treatment (Jeon et al. 2016).

As addressed above, once the samples are frozen in LN, no changes occur in physiological metabolism and cell division (Benson 2008; Harding 2004). For operation convenience, in most of the cryopreservation or cryotherapy studies, the samples are frozen in LN for 30 to $60 \mathrm{~min}$. Taglienti et al. (2013) found that shoot regrowth levels were higher ( 80 to $90 \%$ ), but ArLV-free frequencies were much lower (20 to $30 \%$ ) in shoot tips of globe artichoke plants that were frozen in $\mathrm{LN}$ for $15 \mathrm{~min}$ than those for $30 \mathrm{~min}$. CSVd eradication frequencies were about $13 \%$ when shoot tips of chrysanthemum were exposed to $\mathrm{LN}$ for 1 to $3 \mathrm{~h}$, and decreased to about $7 \%$ when the exposure durations to LN increased to $5 \mathrm{~h}$ (Jeon et al. 2016). The reasons underlying these results are unknown and need further research.

Dhital et al. (2009) compared the effectiveness of vitrification and encapsulation-vitrification on PLRV and potato virus Y (PVY) eradication in potato. They found that vitrification cryotherapy produced about 37 and $42 \%$ of PLRV- and PVY-free potato plants, respectively, which was higher than the 15\% PLRV- and 19\% PVY-free potato plants obtained by encapsulation-vitrification. Further studies are needed to clarify these effects in other pathogen-host combinations.

Results discussed above suggest that adjustments of cryoprocedures may improve pathogen eradication, thus decreasing pathogen cryopreservation, and vice versa (Fig. 1).

\section{Further Prospects}

Most of the current cryotherapy research has made use of previously developed procedures for the cryopreservation (Dumet et al. 2011; B. Wang et al. 2014; M. R. Wang et al. 2018a; Q. C. Wang and Valkonen 2009; Q. C. Wang et al. 2009). As discussed above, a few studies reported that the size of shoot tips (Jeon et al. 2016; Li et al. 2018b), the type of plant vitrification solution (Jeon et al. 2016), and the durations of exposure to plant vitrification solution (Jeon et al. 2016; Taglienti et al. 2013) affected the effectiveness of the cryotherapy procedure. These data suggest it may be necessary to modify standard cryopreservation procedures to improve their effectiveness when they are used in cryotherapy applications that seek to either eradicate or preserve the pathogens.

Additional studies of genetic stability and field performance evaluations of pathogen-free plants derived from cryotherapy should be performed to clarify that pathogen-free plants produced by cryotherapy are genetic stable and true-to-type, in order to accelerate their release to agricultural production. More efforts should be exerted to test pathogen cryopreservation in various pathogen-host combinations, particularly pathogen-infected broad-spectrum host plants like Nicotiana spp., Cucumis sativus, and Solanum lycopersicum. Although the published study did not detect obvious variations in genetic stability of cryopreserved ASGV, more investigations are needed to identify the genetic stability of other cryopreserved pathogens.
More sensitive methods are needed to detect pathogens in both pathogen eradication and preservation programs. Genomic technologies are revolutionizing detection techniques for plant pathogens. Application of next-generation sequencing technologies to cryobiotechnology research could be used to confirm the presence or absence of pathogens in plants and to better understand their spatial distribution within shoot tips (Boonham et al. 2014; Maree et al. 2018). With this information, improved methods for both cryotherapy and pathogen-host cryopreservation methods could be developed.

\section{Conclusion}

Cryopreservation technologies have facilitated the long-term preservation of plant collections, i.e., cryo-bankings. Since 1997, shoot tip cryotherapy has been established as a new biotechnology to eradicate pathogens from vegetatively propagated plant germplasm. Cryotherapy methods rarely produce $100 \%$ of the pathogen-free plants, and under some conditions, the cryopreservation process can be used to conserve pathogens within the shoot tips. Long term storage of these infected shoot tips in LN could provide a stable, costeffective system for long-term preserving obligate plant pathogens. Thus, cryobiotechnology functions as a double-edged sword, where it can be used to both eradicate and cryopreserve plant pathogens, particularly viruses, phytoplasmas, and viroids. A number of the studies have reported successful cryopreservation of fungi and bacteria (Homolka 2013; Tedeschi and Paoli 2011; Webb et al. 2018), thus enabling cryopreservation techniques to preserve for long term the major plant pathogens.

\section{Literature Cited}

Bai, J., Chen, X., Lu, X., Guo, H., Xin, X., and Zhang, Z. 2012. Can cryopreservation eliminate the potato virus $\mathrm{X}(\mathrm{PVX})$ and potato spindle tuber viroid (PSTVd)? Biosci. Methods 3:34-40.

Barba, M., Hosakawa, M., Wang, Q. C., Taglienti, A., and Zhang, Z. 2017. Viroid elimination by thermotherapy, cold therapy, tissue culture, in vitro micrografting, or cryotherapy. Pages $425-435$ in: Viroids and Satellites. A. Hadidi, R. Flores, J. W. Randles, and P. Palukaitis, eds. Academic Press, Oxford.

Bayati, S., Shams-Bakhsh, M., and Moini, A. 2011. Elimination of grapevine virus A (GVA) by cryotherapy and electrotherapy. J. Agric. Sci. Technol. 13: 443-450.

Benson, E. E. 2008. Cryopreservation of phytodiversity: a critical appraisal of theory \& practice. Crit. Rev. Plant Sci. 27:141-219.

Bettoni, J. C., Costac, M. D., Souza, J. A., Volk, G. M., Nickele, O., Silvaa, F. N., and Kretzschmar, A. A. 2018. Cryotherapy by encapsulation-dehydration is effective for in vitro eradication of latent viruses from 'Marubakaido' apple rootstock. J. Biotechnol. 269:1-7.

Bi, W. L., Hao, X. Y., Cui, Z. H., Pathirana, R., Volk, G. M., and Wang, Q. C. 2018a. Shoot tip cryotherapy for efficient eradication of grapevine leafrollassociated virus-3 from diseased grapevine in vitro plants. Ann. Appl. Biol. 173:261-270.

Bi, W. L., Hao, X. Y., Cui, Z. H., Volk, G. M., and Wang, Q. C. 2018b. Dropletvitrification cryopreservation of in vitro-grown shoot tips of grapevine (Vitis spp.). In Vitro Cell. Dev. Biol. Plant 54:590-599.

Bi, W. L., Pan, C., Hao, X. Y., Cui, Z. H., Kher, M. M., Marković, Z., Wang, Q. C. and Teixeira, S. J. A. 2017. Cryopreservation of grapevine (Vitis spp.) -a review. In Vitro Cell. Dev. Biol. Plant 53:449-460.

Boonham, N., Kreuze, J., Winter, S., van der Vlugt, R., Bergervoet, J., Tomlinson, J., and Mumford, R. 2014. Methods in virus diagnostics: from ELISA to next generation sequencing. Virus Res. 186:20-31.

Brison, M., Boucaud, M. T., Pierronnet, A., and Dosba, F. 1997. Effect of cryopreservation on the sanitary state of a cv. Prunus rootstock experimentally contaminated with Plum pox potyvirus. Plant Sci. 123:189-196.

Cambra, M., Boscia, D., Gil, M., Bertolini, E., and Olmos, A. 2011. Immunology and immunological assays applied to the detection, diagnosis and control of fruit tree viruses. Pages 303-313 in: Virus and Virus-Like Diseases of Pome and Stone Fruits. A. Hadidi, M. Barba, W. Candresse, and W. Jelkmann, eds. APS Press, St Paul, MN.

Chen, P., Buss, G. R., Tolin, S. A., and Veilleux, R. E. 2003. Tissue culture method for the preservation of Soybean mosaic virus.Plant Cell Tiss. Org. Cult. 74: 185-192.

Crotty, S., Maag, D., Arnold, J. J., Zhong, W., Lau, J. Y., Hong, Z., Andino, R., and Cameron, C. E. 2000. The broad-spectrum antiviral ribonucleoside ribavirin is an RNA virus mutagen. Nat. Med. 6:1375-1379.

Dawson, W. O., and Lozoya, S. H. 1984. Examination of the mode of action of ribavirin against Tobacco mosaic virus. Intervirol. 22:77-84.

Dhital, S. P., Lim, H. T., and Manandhar, H. K. 2009. Elimination of potato viruses (PLRV and PVY) by cryopreservation of in vitro grown shoot tips of potato (Solanum tuberosum L.). Hortic. Environ. Biotechnol. 50:233-239. 




Dr. Lei Zhao

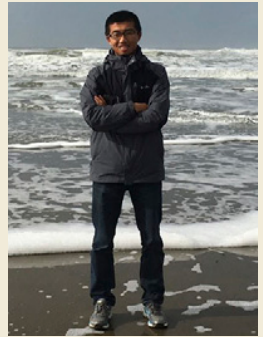

Dr. Zhenhua Cui



Min-Rui Wang

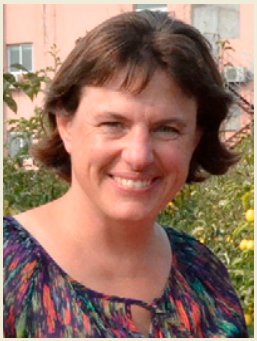

Gayle Volk

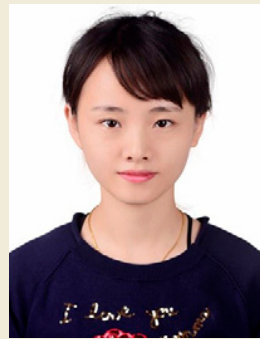

Jing-Wei Li

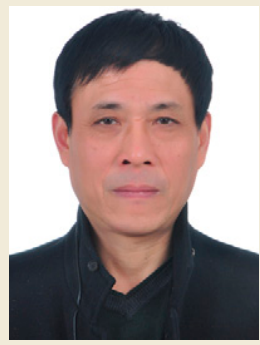

Qiaochun Wang
Dr. Lei Zhao is a lecturer of plant pathology in the College of Plant Protection, Northwest A\&F University, China. He received his master's degree and Ph.D. from the College of Plant Protection of Northwest A\&F University in 2013 and 2016, respectively. His research focuses on plant virus and phytoplasma diseases in field crops and fruit trees. In addition, he is also interested in developments of new molecular methods for detection of viruses that infect vegetables and fruit trees. Since 2013, he has published more than 10 scientific articles in top international journals such as MPMI and Plant Disease.

Min-Rui Wang is a Ph.D. student from the College of Horticulture at Northwest A\&F University, China. He started his Ph.D. study in 2015, during which time he spent two years as a visiting Ph.D. student at the Norwegian Institute of Bioecomomy Research (NIBIO), Norway. His Ph.D. study focuses on plant cryopreservation, cryotherapy for pathogen eradication, and in vitro techniques for virus eradication. He has published one book chapter and eight scientific articles in international top journals such as Plant Pathology, Plant Disease, and Plant Methods.

Jing-Wei $\mathrm{Li}$ is a Ph.D. student at the College of Horticulture at Northwest A\&F University, China. She started her Ph.D. study in 2014, and spent two years as a visiting Ph.D. student in Kyoto University, Japan. Her study is centered on developments of cryopreservation methods for long-term preservation of horticulture plant germplasm including potato, chrysanthemum, blueberry, apple, and lily. She is also interested in cryotherapy for plant pathogen eradication and virus cryopreservation. Since her master's degree study in 2011, she has published 12 research and review articles in international journals such as Biotechnology Advances, Plant Methods, and Applied Microbiology and Biotechnology.

Dr. Zhenhua Cui majored in horticulture since his graduate study. Dr. Cui's research interests include plant viruses, including virus detection, virus eradication by cryotherapy and micrografting, and graft incompatibility induced by grapevine viruses. The grafting incompatibility induced by grapevine viruses differed in various rootstock-scion combinations and causes varying levels of damage, depending on the infected virus variety. The mixed infection of GLRaV-1 and GVA interests Dr. Cui because of its remarkable detrimental effect compared with single infection of GLRaV-1. This observation leads Dr. Cui's research on revealing the role of GVA in the graft incompatibility induced by mixed infection of GVA and GLRaV-1. The evaluation of rootstock virus tolerance is also part of Dr. Cui's research.

Gayle Volk (Ph.D., Cornell University, 1998) is a plant physiologist at the USDA-ARS National Laboratory for Genetic Resources Preservation in Fort Collins, Colorado. Her research focuses on the conservation and preservation of clonally propagated fruit and vegetable crops in the National Plant Germplasm System (NPGS). She has performed ultrastructural, biophysical, and molecular studies to understand the mechanism of plant shoot tip cryopreservation and has developed methods for cryopreserving garlic, citrus, Vitis, Prunus, and many other crops. She has also used shoot tip cryopreservation techniques to eradicate pathogens from plant tissues. As part of her interest in conserving plant genetic resources, she coauthored the Global Conservation Strategy for Apple and applied molecular marker techniques to assess the NPGS apple collection quality and coverage.

Qiaochun Wang is a full-time professor at the College of Horticulture, Northwest A\&F University, China. He received his Ph. D. from the Department of Plant Protection of Hebrew University in Jerusalem, Israel, in 2003. From 2003 to 2008, he worked as a visiting professor in the Department of Applied Biology of the University of Helsinki, Finland. Since then, he returned to work in China. His research focuses on cryopreservation of plant germplasm and cryotherapy for pathogen eradication. He has published about 120 scientific articles and book chapters since 1988. He has served as an associate editor for Plant Methods and Plant Disease, and has held editorial board memberships with Plant Cell Reports, Plant Cell, Tissue and Organ Culture, Annals of Applied Biology, Acta Physiologia Plantarum, and In Vitro Cellular \& Developmental Biology-Plant.
Ding, F., Jin, S. X., Hong, N., Zhong, Y., Cao, Q., Yi, G. J., and Wang, G. P. 2008. Vitrification-cryopreservation, an efficient method for eliminating Candidatus Libero bacterasiaticus, the citrus Huanglongbing pathogen, from in vitro adult shoot tips. Plant Cell Rep. 27:241-250.

Dumet, D., Korie, S., and Adeyemi, A. 2011. Cryobanking cassava germplasm at IITA. Acta Hortic. 908:439-446.

Ellis, D., Skogerboe, D., Andre, C., Hellier, B., and Volk, G. 2006. Implementation of garlic cryopreservation techniques in the national plant germplasm system. Cryo Lett. 27:99-106.
Feng, C. H., Yin, Z., Ma, Y., Zhang, Z., Chen, L., Wang, B., Li, B., Huang, Y., and Wang, Q. C. 2011. Cryopreservation of sweet potato (Ipomoea batatas) and its pathogen eradication by cryotherapy. Biotechnol. Adv. 29:84-93.

Flores, R., Minoia, S., López-Carrasco, A., Delgado, S., Martínez, D. A. A. E., and Kalantidish, K. 2017. Viroid replication. Pages 71-81 in: Viroids and Satellites. A. Hadidi, R. Flores, J. W. Randles, and P. Palukaitis, eds. Academic Press, London.

Fukumoto, F. 2008. Preservation of Alfalfa mosaic virus by freezing and freezedrying and similarities to Cucumoviruses. J. Gen. Plant Pathol. 74:164-170. 
Fukumoto, F., and Tochinara, H. 1998. Preservation of purified Peanut stripe and Turnip mosaic Potyviruses by freezing and freeze-drying. J. Phytopathol. 146: 89-95.

Gallard, A., Mallet, R., Chevalier, M., and Grapin, A. 2011. Limited elimination of two viruses by cryotherapy of Pelargonium apices related to virus distribution. Cryo Lett. 32:111-122.

Grivell, A. R., Grivell, C. J., Jackson, J. F., and Nicholas, D. J. 1971. Preservation of lettuce necrotic yellows and some other plant viruses by dehydration with silica gel. J. Gen. Virol. 12:55-58.

Hadidi, A., and Barba, M. 2011. Economic impact of pome and stone fruit viruses and viroids. Pages 1-7 in: Virus and Virus-Like Diseases of Pome and Stone Fruits. A. Hadidi, M. Barba, W. Candresse, and W. Jelkman, eds. APS Press, St Paul, MN.

Hammond, R. W. 2017. Economic significance of viroids in vegetable and field crops. Pages 5-13 in: Viroids and Satellites. A. Hadidi, R. Flores, J. W. Randles, and P. Palukaitis, eds. Academic Press, Oxford.

Harding, K. 2004. Genetic integrity of cryopreserved plant cells: a review. Cryo Lett. 25:3-22.

Helliod, B., Panis, B., Poumay, Y., Swenen, R., Lepoivre, P., and Frison, E. 2002. Cryopreservation for the elimination of cucumber mosaic and banana streak viruses from banana (Musa spp.). Plant Cell Rep. 20:1117-1122.

Hollings, M., and Stone, O. M. 1970. The long-term survival of some plant viruses preserved by lyophilization. Ann. Appl. Biol. 65:411-418

Homolka, L. 2013. Methods of cryopreservation in Fungi. Pages 9-16 in: Laboratory Protocols in Fungal Biology: Current Methods in Fungal Biology. V. K. Gupta, M. G. Tuohy, M. Ayyachamy, K. M. Turner, and A. O'Donovan, eds. Springer, New York.

Hull, R. 2002. Matthews' plant virology, 4th Ed. Academic Press, London.

Infante, R., Fiore, N., and Seibert, E. 2008. Preservation of Grape fanleaf virus on callus culture of Vitis vinifera cv. Cabernet Sauvignon. Acta Phytopath. Entomol. Hung. 43:101-108.

Jeon, S. M., Naing, A. H., Kim, H. H., Chung, M. Y., Lim, K. B., and Kim, C. K. 2016. Elimination of chrysanthemum stunt viroid and chrysanthemum chlorotic mottle viroid from infected chrysanthemum by cryopreservation. Protoplasma 253:1135-1144.

Jong, S. H., Dong, K. K., and Jae, K. S. 2013. Production of yam mosaic virus (YMV)-free Dioscorea opposita plants by cryotherapy of shoot-tips. Cryo Lett. 34:149-157.

Kumar, J., Singh, S. P., and Kianian, S. F. 2017. Engineering resistance to plant viruses: present status and future prospects. Pages 75-100 in: Current Developments in Biotechnology and Bioengineering. S. K. Dubey, A. Pandey, and R. S. Sangwan, eds. Elsevier.

Kushnarenko, S., Romadanova, N., Aralbayeva, M., Zholamanova, S., Alexandrova, A., and Karpova, O. 2017. Combined ribavirin treatment and cryotherapy for efficient Potato virus $M$ and Potato virus $S$ eradication in potato (Solanum tuberosum L.) in vitro shoots. In Vitro Cell. Dev. Biol. Plant 53:425-432.

Laimer, M., and Barba, M. 2011. Elimination of systemic pathogens by thermotherapy, tissue culture, or in vitro micrografting. Pages 389-393 in: Virus and Virus-Like Diseases of Pome and Stone Fruits. A. Hadidi, M. Barba, W. Candresse, and W. Jelkman, eds. APS Press, St. Paul, MN.

Li, B. Q., Feng, C. H., Hu, L. Y., Wang, R. R., and Wang, Q. C. 2016. Shoot tip culture and cryopreservation for eradication of apple stem pitting virus (ASPV) and apple stem grooving virus (ASGV) from apple rootstocks 'M9' and 'M26'. Ann. Appl. Biol. 168:142-150.

Li, J. W., Chen, H. Y., Li, J., Zhang, Z., Blystad, D. R., and Wang, Q. C. 2018a. Growth, microtuber production and physiological metabolism in virus-free and virus-infected potato in vitro plantlets grown under $\mathrm{NaCl}$-induced salt stress. Eur. J. Plant Pathol. 152:417-432.

Li, J. W., Hosokawa, M., Nabeshima, T., Motoki, K., Yamada, H., and Wang, Q. C. 2019. Cryopreservation of viroid-infected chrysanthemum shoot tips. Sci. Hortic. (Amsterdam) 244:1-9.

Li, J. W., Wang, M. R., Chen, H. Y., Zhao, L., Cui, Z. H., Zhang, Z., Blystad, D. R., and Wang, Q. C. 2018b. Long-term preservation of potato leafroll virus, potato virus $\mathrm{S}$ and potato spindle tuber viroid in cryopreserved shoot tips. Appl. Microbiol. Biotechnol. 102:10743-10754.

Liu, J., Zhang, X., Yang, Y., Hong, N., Wang, G., Wang, A., and Wang, L. 2016. Characterization of virus-derived small interfering RNAs in Apple stem grooving virus-infected in vitro-cultured Pyrus pyrifolia shoot tips in response to high temperature treatment. Virol. J. 13:166.

Lomonossoff, G. P., and Evans, D. J. 2011. Applications of plant viruses in bionanotechnology. Curr. Top. Microbiol. Immunol. 375:245-264.

Maree, H. J., Fox, A., Rwahnih, M. A., Boonham, N., and Candresse, Th. 2018. Application of HTS for routine plant virus diagnostics: State of the art and challenges. Front. Plant Sci. 9:1082.

Marković, Z., Preiner, D., Stupić, D., Andabaka, Ž., Šimon, S., Vončina, D., Maletić, E., Karoglan, K. J., Chatelet, P., and Engelmann, F. 2015. Cryopreservation and cryotherapy of grapevine (Vitis vinifera L.). Vitis 54: 247-251.

McKinney, H. H., Silver, G., and Greeley, L. W. 1965. Longevity of some plant viruses stored in chemically dehydrated tissues. Phytopathology 55:1043-1044.

Murashige, T., and Skoog, F. 1962. A revised medium for rapid growth and bioassays with tobacco cell cultures. Physiol. Plant. 15:473-497.
Nishizawa, S., Sakai, A., Amano, Y., and Matsuzawa, T. 1993. Cryopreservation of asparagus (Asparagus officinalis L.) embryogenic suspension cells and subsequent plant regeneration by vitrification. Plant Sci. 91:67-73.

Nukari, A., Laamanen, J., Uosukainen, M., and Lemmetty, A. 2014. Comparison of virus eradication of Apple mosaic virus from hop by encapsulation-dehydration cryotherapy and meristem culture methods. Acta Hortic. 1039:113-119.

Panattoni, A., Luvisi, A., and Triolo, E. 2013. Elimination of viruses in plants: twenty years of progress. Span. J. Agric. Res. 11:173-188.

Pathirana, R., McLachlan, A., Hedderley, D., Carra, A., Carimi, F., and Panis, B. 2013. Removal of leafroll viruses from infected grapevine plants by droplet vitrification. Acta Hortic. 1083:491-498.

Purcifull, D. E. 1975. Preservation of plant virus antigens by freeze-drying. Phytopathology 65:1202-1205.

Reed, P., and Foster, J. A. 2011. Exclusion of pome and stone fruit viruses, viroids and phytoplasmas by certification and quarantine. Pages 381-388 in: Virus and Virus-Like Diseases of Pome and Stone Fruits. A. Hadidi, M. Barba, W. Candresse, and W. Jelkman, eds. APS Press, St Paul, MN.

Romadanova, N. V., Natalya, V., Mishustina, S. A., Gritsenko, D. A., Omasheva, M. Y., Galiakparov, N. N., Reed, B. M., and Kushnarenko, S. V. 2016 Cryotherapy as a method for reducing the virus in infection of apples (Malus sp.). Cryo Lett. 37:1-9.

Roy, A. S. 2011. Control measures of pome and stone fruit viruses, viroids, and phytoplasmas: role of international organizations. Pages 407-413 in: Virus and Virus-Like Diseases of Pome and Stone Fruits. A. Hadidi, M. Barba, W. Candresse, and W. Jelkman, eds. APS Press, St Paul, MN.

Sakai, A., Kobayash, S., and Oiyama, I. 1990. Cryopreservation of nucellar cells of navel orange (Citrus sinensis Osb. var. brasiliensis Tanaka) by vitrification. Plant Cell Rep. 9:30-33

Salazar-González, J. A., Banuelos-Hernandez, B., and Rosales-Mendoza, S. 2015. Current status of viral expression systems in plants and perspectives for oral vaccines development. Plant Mol. Biol. 87:203-217.

Şeker, M. G., Suzerer, V., Elibuyuk, I. O., and Ciftci, Y. 2015. In vitro elimination of PPV from infected apricot shoot tips via chemotherapy and cryotherapy. Int J. Agric. Biol. 17:1066-1070.

Škorić, D. 2017. Viroid biology. Pages 53-61 in: Viroids and Satellites. A. Hadidi, R. Flores, J. W. Randles, and P. Palukaitis, eds. Academic Press, Oxford.

Taglienti, A., Tiberini, A., and Barba, M. 2013. Cryotherapy: a new tool for the elimination of artichoke viruses. J. Plant Pathol. 95:597-602.

Tavazza, R., Lucioli, A., Benelli, C., Giorgi, D., D'Aloisio, E., and Papacchioli, V. 2013. Cryopreservation in artichoke: towards a phytosanitary qualified germplasm collection. Ann. Appl. Biol. 163:231-241.

Tedeschi, R., and Paoli, P. D. 2011. Collection and preservation of frozen microorganisms. Pages 313-326 in: Methods in Molecular Biology, vol 675. N. J. Clifton, ed. Humana Press, Totowa, NJ.

Vieira, R. L., Lima da Silva, A., Zaffari, G. R., Steinmacher, D. A., de Freitas Fraga, H. P., and Guerra, M. P. 2015. Efficient elimination of virus complex from garlic (Allium sativum L.) by cryotherapy of shoot tips. Acta Physiol. Plant. 37:1733.

Volk, G., Bonnart, R., Krueger, R. R., and Lee, R. 2012. Conservation of U.S citrus collections using cryopreservation. Meeting abstract. https://www.ars. usda.gov/research/publications/publication/?seqNo115=281506

Wang, B., Wang, R. R., Cui, Z. H., Li, J. W., Bi, W. L., Li, B. Q., and Wang, Q. C. 2014. Potential applications of cryogenic technologies to plant genetic improvement and pathogen eradication. Biotechnol. Adv. 32:583-595.

Wang, B., Yin, Z. F., Feng, C. H., Shi, X., Li, Y. P., and Wang, Q. C. 2008 Cryopreservation of potato shoot tips. Pages 46-53 in: Potato I Fruit, Vegetable and Cereal Science and Biotechnology, 2 (Special Issue 1). N. Benkeblia and P. Tennant, eds. Global Science Book, London.

Wang, L. P., Hong, H., Wang, G. P., Xu, W. X., Michelutti, R., and Wang, A. M. 2010. Distribution of Apple stem grooving virus and Apple chlorotic leaf spot virus in infected in vitro pear shoots. Crop Prot. 29:1447-1451.

Wang, M. R., Chen, L., Teixeira da Silva, J. A., Volk, G. M., and Wang, Q. C. 2018a. Cryobiotechnology of apple (Malus spp.): development, progress and future prospects. Plant Cell Rep. 37:689-709.

Wang, M. R., Cui, Z. H., Li, J. W., Hao, X. Y., Zhao, L., and Wang, Q. C. 2018b. In vitro thermotherapy-based methods for plant virus eradication. Plant Methods $14: 87$

Wang, M. R., Yang, W., Zhao, L., Li, J. W., Liu, K., Yu, J. W., Wu, Y. F., and Wang, Q. C. 2018c. Cryopreservation of virus: a novel biotechnology for long-term preservation of virus in shoot tips. Plant Methods 14:47.

Wang, Q. C., Cuellar, W. J., Rajamaki, M. L., Hiraka, Y., and Valkonen, J. P. T. 2008. Combined thermotherapy and cryotherapy for efficient virus eradication: relation of virus distribution, subcellular changes, cell survival and viral RNA degradation in shoot tips. Mol. Plant Pathol. 9:237-250.

Wang, Q. C., Liu, Y., Xie, Y. H., and You, M. 2006. Cryotherapy of potato shoot tips for efficient elimination of Potato leaf roll virus (PLRV) and Potato virus $Y$ (PVY). Potato Res. 49:119-129.

Wang, Q. C., Mawassi, M., Li, P., Gafny, R., Sela, I., and Tanne, E. 2003 Elimination of Grapevine virus A (GVA) by cryopreservation of in vitrogrown shoot tips of Vitis vinifera L. Plant Sci. 165:321-327.

Wang, Q. C., Panis, B., Engelmann, F., Lambardi, M., and Valkonen, J. P. T. 2009 Cryotherapy of shoot tips: a technique for pathogen eradication to produce healthy planting materials and prepare healthy plant genetic resources for cryopreservation. Ann. Appl. Biol. 154:351-363. 
Wang, Q. C., and Valkonen, J. P. T. 2008a. Efficient elimination of Sweetpotato little leaf phytoplasma from sweetpotato by cryotherapy of shoot tips. Plant Pathol. 57:338-347.

Wang, Q. C., and Valkonen, J. P. T. 2008b. Eradication of two viruses which interact synergistically from sweetpotato using shoot tip culture and cryotherapy. J. Virol. Methods 54:135-145.

Wang, Q. C., and Valkonen, J. P. T. 2009. Cryotherapy of shoot tips: novel pathogen eradication method. Trends Plant Sci. 14:119-122.

Wang, R. R., Mou, H. Q., Gao, X. X., Chen, L., Li, M. F., and Wang, Q. C. 2015. Cryopreservation for eradication of Jujube witches' broom phytoplasma from Chinese jujube (Ziziphus jujuba). Ann. Appl. Biol. 166:218-228.

Webb, K. M., Holman, G., Duke, S., Greene, S., and McCluskey, K. 2018. Frozen fungi: cryogenic storage is an effective method to store Fusarium cultures for the long-term. Ann. Appl. Biol. 173:133-140.

White, P. R. 1934. Multiplication of the viruses of tobacco and aucuba mosaic in growing excised tobacco roots. Phytopathology 2:1003-1011.
Yi, J. Y., Lee, G. A., Jeong, J. W., Lee, S. Y., and Lee, Y. G. 2014. Elimination of Potato virus $Y$ (PVY) and Potato leafroll virus (PLRV) using cryotherapy of in vitro-grown potato shoot tips. Korea J. Crop Sci. 59:498-504.

Yordanova, A., Stoimenova, E., and Donev, T. 2000. Prediction of the preservation of freeze-dried Cucumber mosaic virus. Biotechnol. Lett. 22:1779-1782.

Zhang, Z. B., Haugslien, S., Clarke, J. H. L., Spetz, C., Blystad, D. R., and Wang, Q. C. 2014. Cryotherapy could not eradicate Chrysanthemum stunt viroid from infected Argyranthemum maderense 'Yellow Empire'. Acta Hortic.: 201-208.

Zhang, Z. B., Lee, Y. K., Sivertsen, A., Skjeseth, G., Haugslien, S., Clarke, J. H. L., Wang, Q.-C., and Blystad, D.-R. 2016. Low temperature treatment affects elimination and distribution of Chrysanthemum stunt viroid in Argyranthemum. Front. Microbiol. 7:224.

Zhao, L., Wang, M. R., Cui, Z. H., Chen, L., Volk, G. M., and Wang, Q. C. 2018 Combining thermotherapy with cryotherapy for efficient eradication of apple stem grooving virus from infected in vitro-cultured apple shoots. Plant Dis. 102:1574-1580. 